\title{
Primary Intestinal Lymphangiectasia: Is It Always Bad? Two Cases with Different Outcome
}

\author{
Ioannis Xinias $^{\mathrm{a}} \quad$ Antigoni Mavroudi $^{\mathrm{a}} \quad$ Evi Sapountzi $^{\mathrm{c}}$ \\ Agathi Thomaidou $^{a}$ Maria Fotoulaki $^{d}$ Athanasios Kalambakas $^{e}$ \\ Elina Karypidou ${ }^{a} \quad K$ Konstantinos Kollios ${ }^{a} \quad$ Grigorios Pardalos $^{c}$ \\ George Imvrios ${ }^{b}$ \\ ${ }^{a}$ Third Pediatric Department, ${ }^{b}$ Transplantation and Surgery Clinic and ${ }^{\mathrm{C}}$ First Pediatric \\ Department, Hippocration Hospital, and ${ }^{\mathrm{d}}$ Fourth Pediatric Department and \\ eGastroenterology Department, Papageorgiou Hospital, Thessaloniki, Greece
}

\section{Key Words}

Protein-losing enteropathy · Children · Primary intestinal lymphangiectasia - Wireless capsule endoscopy · Outcome

\begin{abstract}
Primary intestinal lymphangiectasia (PIL) or Waldmann's disease is a rare protein-losing gastroenteropathy of unknown etiology. Less than 200 cases have been reported globally. Patients may be asymptomatic or present edema, lymphedema, diarrhea, ascites and other manifestations. We report two pediatric cases with PIL with extremely different outcome in a 3-year follow-up period. The first patient presented with persistent diarrhea, hypoalbuminemia and failure to thrive, while the second patient presented with an abrupt eyelid edema. Hypoproteinemia was the common laboratory finding for the two patients and upper gastrointestinal endoscopy established the diagnosis. The first patient relapsed five times during the follow-up period after the diagnosis had been made and required intravenous albumin administration and micronutrient supplementation. The second patient revealed normal gastrointestinal endoscopy 4 months after the diagnosis had been established; he followed an unrestricted diet and remained asymptomatic throughout the follow-up period. PIL can be either severe, affecting the entire small bowel, leading to lifetime disease, or sometimes affects part of the small bowel, leading to transient disorder.
\end{abstract}


Xinias et al.: Primary Intestinal Lymphangiectasia: Is It Always Bad? Two Cases with Different Outcome

\section{Introduction}

Intestinal lymphangiectasia is a rare protein-losing gastroenteropathy caused by congenital malformation or obstruction of intestinal lymphatic drainage [1]. Factors causing elevated pressure of lymph drainage in the intestinal wall can lead to dilatation and even rupture of the lymphatic vessels which, in turn, results in the leakage of lymphatic fluid [2, 3]. Depending on the cause of the disease, it can be classified into primary or secondary intestinal lymphangiectasia. As lymphatic fluid contains a lot of protein, fat and lymphocytes, leakage of lymph will cause hypoproteinemia, lymphocytopenia and decreased serum levels of immunoglobulin [4].

Primary intestinal lymphangiectasia (PIL) or Waldmann's disease has been described for the first time by Waldmann in 1961 [5]. Since then, less than 200 PIL cases have been reported globally $[2,4]$.

The etiology and the prevalence of the disease are unknown. A diagnosis is usually established before the third year of life, but occasionally a diagnosis may be obtained when the child is older. The disease may be asymptomatic but it may as well exist as a discrete disorder or as part of a syndrome, such as Noonan, Klippel-Trennay-Weber, von Recklinghausen, Hennekam and yellow nail syndrome [1, 5-7].

We report two pediatric cases, diagnosed with PIL at approximately 2 years of age, with extremely different outcome after 3 years of follow-up.

\section{Case 1}

The first patient is a 20-month-old boy who was admitted to our pediatric gastroenterology unit because of persistent diarrhea, hypoalbuminemia and failure to thrive.

The toddler was the first child of the family. Gestation age was 40 weeks and delivery was by caesarean section. The family reported no history of severe systematic diseases and no severe gastrointestinal (GI) problems (irritable bowel syndrome, inflammatory bowel disease, food allergies etc.). The child's neonatal period was uneventful and his psychomotor development was normal.

Introduction of various foods in the diet followed standard recommendations. Until the age of 1 year the child had a normal weight gain with normal body parameters (50th-75th percentile). After this age he suffered from intermittent diarrhea and presented with either watery or creamy stools. At the same time he fell ill from gastroenteritis that relapsed two times within a period of 15 days. Ever since the child presented with 4 or 5 daily defecations of which 2-3 were watery and the other were creamy. His symptoms improved for a brief period of approximately 15 days before a new episode of watery stools and weight loss (approximately $800 \mathrm{~g}$ ) for which he was admitted to a hospital for infectious diseases. His laboratory investigation was negative for bacterial or parasitic infection (urine, blood and feces cultures were negative, and feces microscopy revealed no parasites). Blood investigation revealed hypoproteinemia (total serum protein $2.9 \mathrm{~g} / \mathrm{dl}$ ) and hypoglobulinemia (albu$\min 1.6 \mathrm{~g} / \mathrm{dl}$ ). The laboratory findings prompt a referral to our Pediatric Department for further investigation.

His growth parameters on admission were: body weight 25 th-50th percentile, body length $>90$ th percentile, head circumference 50 th-75th percentile. On observation facial paleness was noted with lack of subcutaneous adipose tissue in the gluteal and abdominal region. No edema was observed, but a small umbilical hernia was detected. Percussion of the abdomen showed flatulence and auscultation revealed increased intestinal peristalsis. The 
Xinias et al.: Primary Intestinal Lymphangiectasia: Is It Always Bad? Two Cases with Different Outcome

liver and the spleen were not palpable. A small hemangioma of $1.5 \mathrm{~cm}$ was present on the lateral aspect of the left arm. The rest of the physical examination was normal.

The patient underwent laboratory investigation as shown in table 1. 24-hour urine sample analysis showed no protein loss through the kidneys. Abdominal ultrasound showed no pathological findings regarding the liver, kidneys or other abdominal organs. The liver showed homogenous architecture and good echogenicity without local damage or increased diameter of the intrahepatic biliary vessels, the diameter of the portal vein was within normal range, and the spleen, pancreas and kidneys showed normal appearance.

Antibody serum levels against rotavirus, adenovirus, parvovirus, Coxsackievirus, EBV, CMV and HIV were not elevated. Stool cultures for bacteria (Salmonella, Shigella, Yersinia, Campylobacter) as well as fecal examination for Clostridium difficile toxin were negative. Stool examination for common parasites was negative too. Blood and urine tests for metabolic disorders showed no pathological values. Total serum IgE and specific IgE antibodies to cow's milk protein were found to be elevated $(>0.35 \mathrm{IU} / \mathrm{ml})$.

A scintiscan of the GI tract by injecting radiolabelled human albumin showed no signs of protein loss through the gut. On upper GI endoscopy normal macroscopic findings were obtained from the esophagus and the stomach, but the first part of the duodenum (D1) was covered with smear. The second part of the duodenum (D2) revealed an edematous intestinal mucosa covered with areas of white exudate extending throughout the length of the small intestine (fig. 1). Four biopsies taken from D1 and D2 revealed lymphangiectasia (histologic findings of lymph vessel dilatation combined with dilatation and malformation of the intestinal villi). A milk elimination diet was started and an amino acid-based milk formula was used as a milk substitute due to elevated specific IgE antibodies to cow's milk protein. Finally the severity and the size of lymphangiectasia were investigated with wireless capsule endoscopy, which revealed lesions throughout the whole length of the small intestine which were sparse in the jejunum and very dense in the ileum (fig. 2, fig. 3, fig. 4).

During the period of hospitalization the child presented with persistent hypoalbuminemia (albumin levels $<2.5 \mathrm{~g} / \mathrm{dl}$ and total serum protein $<4.0 \mathrm{~g} / \mathrm{dl}$ ) which was managed with intravenous (IV) albumin administration ( $1 \mathrm{~g}$ of human albumin $/ \mathrm{kg}$ body weight). In addition he was placed on medium-chain triglyceride (MCT)-enriched formula and was advised to consume foods low in fat. MCTs were administered additionally to his diet.

The patient relapsed for the first time 6 months after the diagnosis had been made. He presented eyelid edema while serum protein was below the lower normal limit (serum albumin $1.8 \mathrm{mg} / \mathrm{dl}$, total serum protein $3.9 \mathrm{mg} / \mathrm{dl}$ ). Management was with administration of IV human albumin. The patient reached satisfactory serum protein levels of 3.4 and $5.8 \mathrm{mg} / \mathrm{dl}$ regarding serum albumin and total serum protein, respectively, before he was discharged.

During a period of three years, despite the milk elimination diet, the child relapsed five times. Each episode was followed by hospital admission. Each time the patient presented with low serum protein levels. Hypoproteinemia was treated with IV human albumin, achieving serum levels of 3.2 and $5 \mathrm{mg} / \mathrm{dl}$ regarding serum albumin and total serum protein, respectively. At the age of 24 months he had low vitamin D and zinc levels $(7.4 \mathrm{ng} / \mathrm{ml}$ and $6.9 \mu \mathrm{mol} / \mathrm{l}$ ) for which he received replacement therapy. The patient had no clinical symptoms or signs of the disease throughout the follow-up period. 
Xinias et al.: Primary Intestinal Lymphangiectasia: Is It Always Bad? Two Cases with Different Outcome

\section{Case 2}

The second case is a 26-month-old boy who was admitted to hospital when he presented an abrupt eyelid edema. Three days before admission the child also presented irritability, constipation and abdominal pain. In regards to the child's history he was delivered by caesarean section after 37 weeks of gestation. His birth weight was 2,630 g and had a negative personal and family history of genetic disorders. The child underwent all the compulsory immunizations for his age.

On clinical examination both eyelids were edematous, but no edema was present in the lower limps and the scrotum. The child was not febrile. His body weight was $12,400 \mathrm{~g}$ and arterial pressure was $85-65 \mathrm{~mm} \mathrm{Hg}$. The rest of the physical examination was normal. Abdominal ultrasound showed homogenous architecture and good echogenicity of the liver tissue and normal intrahepatic biliary vessels. Echogenic findings regarding the spleen, pancreas and kidneys were also normal.

The patient underwent laboratory investigation which revealed hypoproteinemia, normal liver function and negative markers for infection (table 2). 24-hour urine sample analysis showed no pathological loss of protein through the kidneys. A more extensive laboratory investigation was by protein electrophoresis which showed increased $\alpha_{1}$ - and $\alpha_{2}$-globulins and decreased $\gamma$-globulins $(0.45,1.6$ and $0.25 \mathrm{~g} / \mathrm{dl}$, respectively) and normal $\beta$-globulin levels $(0.65 \mathrm{~g} / \mathrm{dl})$. Immunophenotyping showed a decreased number of T-helper lymphocytes and increased T-cytotoxic cells. Magnetic resonance imaging of the upper and lower abdomen revealed a small amount of fluid in the peritoneum and on the left side of the pleura. Scintiscan by injecting human albumin showed no signs of albumin loss through the GI tract. Specific IgE antibodies to cow's milk proteins were negative, total serum IgE was not elevated and stool examination for undigested muscle fibers, lipoid granules and parasites was negative. The patient was then subjected to upper GI endoscopy which revealed increased lymph diffusion through the ruptured lymph vessels appearing as white spots on the duodenal mucosa (fig. 5). Four biopsies taken from D1 and D2 revealed histologic alterations of the mucosa suggestive of lymphangiectasia. The histologic findings described were lymph vessel dilatation combined with dilatation and malformation of the intestinal villi. The extent of the lesions was assessed by capsule endoscopy, which showed that all the duodenum mucosa and a small part of the jejunum $(\sim 60 \mathrm{~cm})$ were affected (fig. 6).

Hypoalbuminemia was managed with IV albumin administration. In addition the patient was placed on a MCT-enriched formula with appropriate dietary instructions. Re-evaluation 2 months later showed normal serum protein values (serum albumin $4.0 \mathrm{mg} / \mathrm{dl}$, total serum protein $6.2 \mathrm{mg} / \mathrm{dl}$ ) as well as normal physical examination. Upper GI endoscopy 4 months after the diagnosis was also normal. He was placed on an unrestricted diet, having no symptoms and normal laboratory data. On follow-up at 6, 12, 18 and 24 months, laboratory findings were normal and the child remained asymptomatic throughout the follow-up period.

\section{Discussion}

Intestinal lymphangiectasia is an uncommon disorder and an important cause of protein-losing enteropathy. PIL is generally diagnosed before 3 years of age, equally affecting boys and girls. The prevalence of the disease is unknown. Patients with PIL often present edema, lymphedema, diarrhea, ascites that may be complicated by fatigue, abdominal pain, nausea, vomiting, weight loss, inability to gain weight, iron deficiency anemia and obstruc- 
tive ileus. Other major features are lymphopenia, hypoalbuminemia, and hypogammaglobulinemia due to lymph leakage from the ruptured lymph vessels $[6,8]$.

In a retrospective analysis of 84 cases in 2010 [4], the most common symptoms were edema, diarrhea, ascites and lymphedema, present in 78, 62, 41 and $22 \%$, respectively. In our study both patients presented common clinical manifestations of PIL, such as intermittent diarrhea, malabsorptive syndrome and failure to thrive in the first case, while an abrupt and symmetric eyelid edema was the most conspicuous clinical symptom in the second case. PIL diagnosis in our patients was achieved under the age of 3 years in both patients as it is also reported in other studies $[1,2,9,10]$. In regards to the first case the lack of clinical response to an amino acid formula suggested that the diagnosis of cow's milk allergy was unlikely.

The diagnosis of PIL in our cases was made by upper GI endoscopy and confirmed with biopsies and histologic examination. Other authors report that $86 \%$ of the diagnoses are achieved by endoscopy alone and the rest through other methods, such as surgery, capsule endoscopy, double-balloon enteroscopy, etc. [4].

Treatment options are discussed in several publications. Lifelong dietary modification with high protein, fat restriction and substitution with MCTs and vitamin supplements remains the cornerstone in the management of PIL [11]. Exclusion of long-chain fatty acids prevents the engorgement and rupture of malformed lymphatics while MCTs get directly absorbed into the portal venous circulation. In case of poor response to this treatment, partial or total parenteral nutrition should be considered. Other treatment modalities described in the literature with variable efficacy include antiplasmin therapy, octreotide, corticosteroids, small bowel resection, albumin infusions, peritoneovenous (Levine) shunt and intestinal transplant $[1,11-15]$.

A report of Wen et al. [4] showed that all of the 4 children investigated showed a good response to nutrition therapy with low long-chain triglycerides and high-protein diet supplemented with MCT after the diagnosis of PIL. The authors also implemented parenteral nutrition support in 3 of the 4 children, from once per day to twice per week. Edema, diarrhea and ascites were greatly alleviated, and laboratory parameters also indicated a great improvement. After discharge, all of the 4 children who continued the diet achieved symptom control and were still stable without symptom relapse. However, in 1 case the bilateral lower limb edema showed no sign of improvement. In the same study a retrospective analysis showed apparent improvement in 24 out of 84 patients (63\%) after initiation of diet treatment, and normal laboratory parameters were obtained in the patients who were mostly $(85 \%)$ children $(\mathrm{p}<0.05)$. Octreotide and antiplasmin proved effective in 3 and 1 patient, respectively.

The management of our patients was IV human albumin administration during the acute phase. The long-term therapy was a low-fat diet with administration of MCTs as well as vitamin D and zinc supplementation in the first case. Approximately 3-4 weeks after the application of the treatment the first child showed clinical improvement, resolution of hypoalbuminemia and improvement of stool number and composition. However, within the next 30 months, after he had been diagnosed, he relapsed five times having need for IV human albumin administration and addition of vitamin D and zinc. Fortunately body parameters remained normal during the whole follow-up period.

On the other hand, the second patient showed very different outcome. His re-evaluation 2 months later showed normal serum protein, normal physical examination, and 4 months after he had been diagnosed he had a normal upper GI endoscopy. Follow-up at 6, 12, 18 and 24 months revealed normal laboratory findings, and the child was without symptoms and signs receiving a full diet. 
The above-mentioned is in accordance with a report of Munck et al. [9], who reviewed 6 children with PIL and reported that 1 child out of 3 had normal biological parameters and tolerated a normal diet a few years after the diagnosis had been made. The same investigators reported that relaxation of the diet by 2 patients who had moderate hypoalbuminemia and lymphopenia led to severe clinical relapses 14 and 17 years after the diagnosis had been established [9]. In another study the authors reviewed 84 patients with PIL and reported that 2 cases turned to complete remission even withdrawing diet intervention [4]. This observation shows that some cases of PIL can have complete disease remission, without sings and symptoms, few years after diagnosis, tolerating a full normal diet.

In regards to the adverse events of PIL it is not clear whether malignancy, especially lymphoma, is fortuitous or related to the disease. In 84 patients reviewed in 2010 [4], four cases (5\%) had a malignant transformation of lymphoma, and the average time from PIL onset to lymphoma diagnosis was 31 years (range 19-45 years). Lymphoma mainly affects the digestive system (stomach, small intestine and ileum), but may also affect the retroperitoneum and the mediastinum.

Recurrent and opportunistic infections are not rare. Patients suffering from PIL have a significantly higher likelihood of infections due to moderate or severe hypogammaglobulinemia and lymphopenia (e.g. Streptococcus G, meningitis, Cryptococcus, cytomegalovirus) $[16,17]$. We saw no infections at 3 years follow-up in our 2 cases even with low levels of IgG.

\section{Conclusion}

PIL is a rare condition that can appear with common features (diarrhea, failure to thrive, nausea, vomiting, abdominal pain, hypoglobulinemia, skin edema). It can be severe, affecting the entire small bowel, persistent and difficult to manage, leading to lifetime disease. The risk of cancer in these cases should be taken into account. On the other hand the disease can be 'soft', affecting part of the bowel, transient and easy to manage with dietary interventions. The risk of recurrence seems to be very low, at least a few years after a diagnosis is obtained.

\section{References}

1 Vignes S, Bellanger J: Primary intestinal lymphangiectasia (Waldmann's disease). Orphanet J Rare Dis 2008;3:5.

2 Lee J, Kong MS: Primary intestinal lymphangiectasia diagnosed by endoscopy following the intake of a high-fat meal. Eur J Pediatr 2008;167:237-239.

-3 Liu NF, Lu Q, Wang CG, Zhou JG: Magnetic resonance imaging as a new method to diagnose protein-losing enteropathy. Lymphology 2008;41:111-115.

4 Wen J, Tang Q, Wu J, Wang Y, Cai W: Primary intestinal lymphangiectasia: four case reports and a review of the literature. Dig Dis Sci 2010;55:3466-3472.

-5 Waldmann TA: Gastrointestinal protein loss demonstrated by Cr-51-labelled albumin. Lancet 1961;2(7194): 121-123.

6 Braamskamp M, Dolman K, Tabbers M: Clinical practice. Protein-losing enteropathy in children. Eur J Pediatr 2010;169:1179-1185.

7 Hauser B, Moreels T, Urbain D, Van Marck V, Pletincx M, Devreker T, Vandenplas Y: Intestinal lymphangiectasia. J Pediatr Gastroenterol Nutr 2009;48:125.

$\checkmark 8$ Vardy PA, Lebenthal E, Shwachmann H: Intestinal lymphangiectasia: a reappraisal. Pediatrics 1975;55: 842-850.

-9 Munck A, Sosa Valencia G, Faure C, Besnard M, Ferkdadji L, Cézard JP, Mougenot JF, Navarro J: Long-term followup of primary intestinal lymphangiectasia in the child. Six case reports. Arch Pediatr 2002;9:388-391.

10 Suresh N, Ganesh R, Sankar J, Sathiyasekaran M: Primary intestinal lymphangiectasia. Indian Pediatr 2009;46:903-906. 
Xinias et al.: Primary Intestinal Lymphangiectasia: Is It Always Bad? Two Cases with Different Outcome

11 Desai AP, Guvenc BH, Carachi R: Evidence for medium chain triglycerides in the treatment of primary intestinal lymphangiectasia. Eur J Pediatr Surg 2009;19:241-245.

12 Tift WL, Lloyd JK: Intestinal lymphangiectasia. Long-term results with MCT diet. Arch Dis Child 1975;50: 269-276.

13 Sari S, Baris Z, Dalgic B: Primary intestinal lymphangiectasia in children: is octreotide an effective and safe option in the treatment? J Pediatr Gastroenterol Nutr 2010;51:454-457.

$\checkmark 14$ Kim NR, Lee SK, Suh YL: Primary intestinal lymphangiectasia successfully treated by segmental resections of small bowel. J Pediatr Surg 2009;44:E13-E17.

15 Tang QY, Wen J, Wu J, Wang Y, Cai W: Clinical outcome of nutrition-oriented intervention for primary intestinal lymphangiectasia. World J Pediatr 2011;7:79-82.

16 Dierselhuis M, Boelens J, Florens GA, Versteegh F, Weemaes C, Wulffraat N: Recurrent and opportunistic infections in children with primary intestinal lymphangiectasia. J Pediatr Gastroenterol Nutr 2007;44: 382-385.

17 Hoshina T, Kusuhara K, Saito M, Hara TA, Matsuura S, Yano T, Aoki T, Hara T: Cytomegalovirus-associated protein-losing enteropathy resulting from lymphangiectasia in an immunocompetent child. Jpn J Infect Dis 2009;62:236-238. 
Xinias et al.: Primary Intestinal Lymphangiectasia: Is It Always Bad? Two Cases with Different Outcome

Table 1. Laboratory investigation in case 1

White blood cells
Absolute count/mm
Polymorphonuclear cells
Lymphocytes
Monocytes
Eosinophils
Coagulation tests (PT, PTT)
Sweat test
Stool cultures for Salmonella, Shigella, Yersinia, Campylobacter, Clostridium difficile
toxin
Stool microscopic examination for common parasites, fat, muscle fibers
Blood biochemistry
Total serum protein
Albumin
Creatinine
SGOT
SGPT
Calcium
Phosphorus

10,800

$56.6 \%$

$19.0 \%$

$13.8 \%$

$12.8 \%$

normal (PT $11.3 \mathrm{~s}$, PTT $34.5 \mathrm{~s})$

normal (sweat chloride level $21 \mathrm{mmol} / \mathrm{l}$ ) negative

negative

$2.7 \mathrm{~g} / \mathrm{dl}$

$1.5 \mathrm{~g} / \mathrm{dl}$

$0.57 \mathrm{mg} / \mathrm{dl}$

$35 \mathrm{U} / \mathrm{ml}$

$18 \mathrm{U} / \mathrm{ml}$

$7.2 \mathrm{mg} / \mathrm{dl}$ (normal: 7.6-10.8 mg/dl)

$4.4 \mathrm{mg} / \mathrm{dl}$

negative

$0.35 \mathrm{U} / \mathrm{ml}$ (normal: $<7.0$ )

negative $(3.0 \mathrm{mg} / \mathrm{l})$

normal

$1.21 \mathrm{~g} / \mathrm{l}$ (normal: $5.30-11$ )

$0.278 \mathrm{~g} / \mathrm{l}$ (normal: 0.64-1.95)

Reduced T-lymphocytes:

CD3: $43 \%$ (normal: $56-80 \%$ )

CD4: 16\% (normal: 31-64\%)

CD29: 11\% (normal: 15-50\%)

CD45RA: 6.5\% (normal: 15-60\%)

negative

$783 \mathrm{IU} / \mathrm{ml}$ (normal: $<100 \mathrm{IU} / \mathrm{ml}$ )

normal values: $<0.35 \mathrm{IU} / \mathrm{ml}$

$\alpha$-lactalbumin: $2.1 \mathrm{IU} / \mathrm{ml}$

$\beta$-lactoglobulin: $1.1 \mathrm{IU} / \mathrm{ml}$

casein: $0.87 \mathrm{IU} / \mathrm{ml}$

beef: $1.1 \mathrm{IU} / \mathrm{ml}$

total milk: $<0.10 \mathrm{IU} / \mathrm{ml}$

$6.9 \mu \mathrm{mol} / \mathrm{l}$ (normal: $9.8-18.1 \mu \mathrm{mol} / \mathrm{l})$

$7.4 \mathrm{ng} / \mathrm{ml}$ (normal: $14-42 \mathrm{ng} / \mathrm{ml}$ ) 
Xinias et al.: Primary Intestinal Lymphangiectasia: Is It Always Bad? Two Cases with Different Outcome

Table 2. Laboratory investigation in case 2

\begin{tabular}{|c|c|}
\hline \multicolumn{2}{|l|}{ Full blood count } \\
\hline Leukocytes $/ \mathrm{mm}^{3}$ & 10,100 \\
\hline Polymorphonuclear cells & $66 \%$ \\
\hline Lymphocytes & $23 \%$ \\
\hline Monocytes & $8 \%$ \\
\hline Eosinophils & $3 \%$ \\
\hline $\mathrm{Hgb}$ & $11.8 \mathrm{~g} / \mathrm{dl}$ \\
\hline Hct & $33 \%$ \\
\hline Platelets $/ \mathrm{mm}^{3}$ & 212,000 \\
\hline ESR & normal (8 $\mathrm{mm}$ in the 1 st hour) \\
\hline Prothrombin time & normal (11.1 s) \\
\hline Activated partial thromboplastin time & normal (34 s) \\
\hline \multicolumn{2}{|l|}{ Blood biochemistry } \\
\hline Total serum protein & $3.1 \mathrm{~g} / \mathrm{dl}$ \\
\hline Albumin & $2.1 \mathrm{~g} / \mathrm{dl}$ \\
\hline SGOT & $32 \mathrm{U} / \mathrm{l}$ \\
\hline SGPT & $18 \mathrm{U} / \mathrm{l}$ \\
\hline Urea & $21 \mathrm{mg} / \mathrm{dl}$ \\
\hline Creatinine & $0.42 \mathrm{mg} / \mathrm{dl}$ \\
\hline $\mathrm{Na}$ & $138 \mathrm{mEq} / \mathrm{l}$ \\
\hline $\mathrm{K}$ & $3.9 \mathrm{mEq} / \mathrm{l}$ \\
\hline Total (direct) bilirubin & $0.2 \mathrm{mg} / \mathrm{dl}$ (direct: $0.03 \mathrm{mg} / \mathrm{dl}$ ) \\
\hline \multicolumn{2}{|l|}{ Immunological investigation } \\
\hline $\begin{array}{l}\text { Antibody serum levels against rotavirus, adenovirus, parvovirus, Coxsackievirus, } \\
\text { EBV, CMV, HIV }\end{array}$ & normal \\
\hline C-reactive protein & negative (2.1 mg/l) \\
\hline Widal \& Wright reactions & negative \\
\hline IgA anti-tissue transglutaminase antibodies & $1.30 \mathrm{U} / \mathrm{ml}($ normal: $<7.0$ ) \\
\hline $\operatorname{IgG}$ & $2.28 \mathrm{~g} / \mathrm{l}$ (normal: $5.30-11$ ) \\
\hline IgM & $0.406 \mathrm{~g} / \mathrm{l}$ (normal: $0.64-1.95$ ) \\
\hline ANA, antigliadin antibodies, antiendomysium antibodies, antireticulin antibodies & negative \\
\hline Total serum IgE & $45 \mathrm{IU} / \mathrm{ml}($ normal: $<100)$ \\
\hline$\alpha$-Lactalbumin, $\beta$-lactoglobulin, casein, total milk-specific IgE & $\begin{array}{l}\text { normal values: }<0.35 \mathrm{IU} / \mathrm{ml} \\
\alpha \text {-lactalbumin: }<0.10 \mathrm{IU} / \mathrm{ml} \\
\beta \text {-lactoglobulin: }<0.10 \mathrm{IU} / \mathrm{ml} \\
\text { casein: }<0.10 \mathrm{IU} / \mathrm{ml} \\
\text { total milk: }<0.10 \mathrm{IU} / \mathrm{l} \\
\text { beef: }<0.10 \mathrm{IU} / \mathrm{ml}\end{array}$ \\
\hline $\begin{array}{l}\text { Fecal microscopic examination for common parasites, fat, muscle fibers and stool } \\
\text { cultures }\end{array}$ & negative \\
\hline Protein electrophoresis & $\begin{array}{l}\alpha_{1} \text {-globulins: } 0.45 \mathrm{~g} / \mathrm{dl} \text { (normal: } 0.2-0.3 \mathrm{~g} / \mathrm{dl} \text { ) } \\
\alpha_{2} \text {-globulins: } 1.6 \mathrm{~g} / \mathrm{dl} \text { (normal: } 0.4-1.0 \mathrm{~g} / \mathrm{dl} \text { ) } \\
\gamma \text {-globulins: } 0.25 \mathrm{~g} / \mathrm{dl} \text { (normal: } 0.7-1.2 \mathrm{~g} / \mathrm{dl} \text { ) } \\
\beta \text {-globulins: } 0.65 \mathrm{~g} / \mathrm{dl} \text { (normal: } 0.5-1.1 \mathrm{~g} / \mathrm{dl} \text { ) }\end{array}$ \\
\hline
\end{tabular}



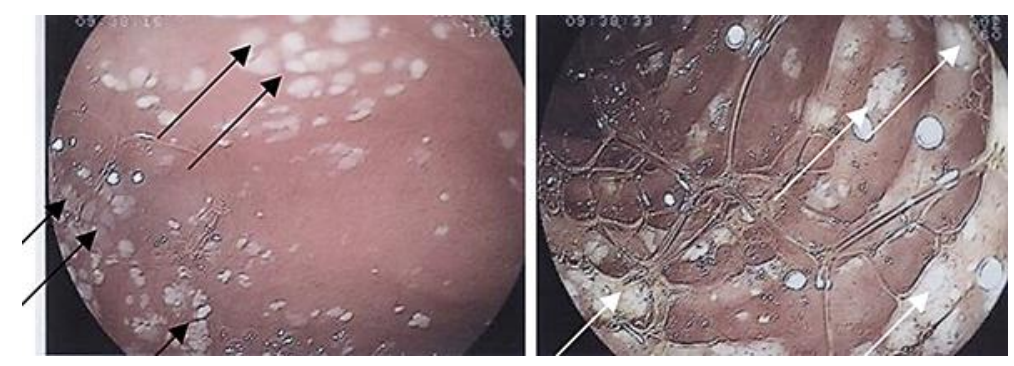

Fig. 1. Case 1. Upper GI endoscopy showing D1 covered with white smear (black arrows). D2 appears with edematous intestinal mucosa covered with areas of white exudate (white arrows).

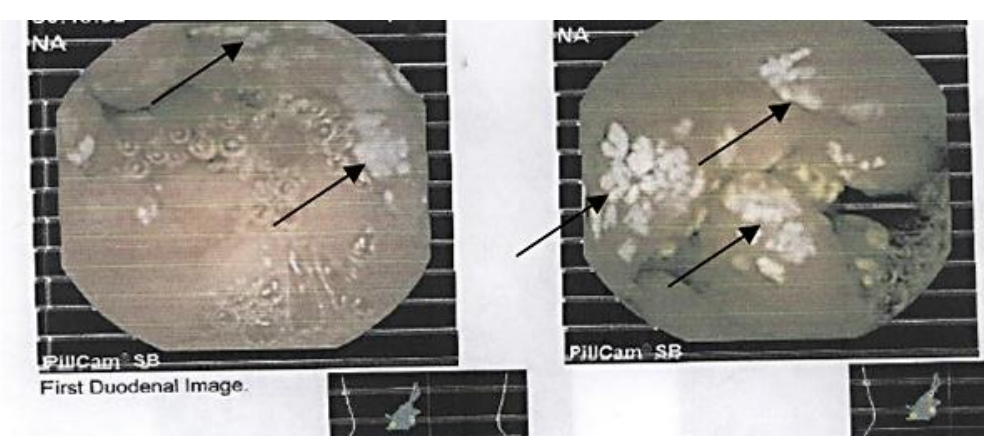

Fig. 2. Case 1. Wireless capsule endoscopy showing white spot lesions on the entire duodenal mucosa (arrows).

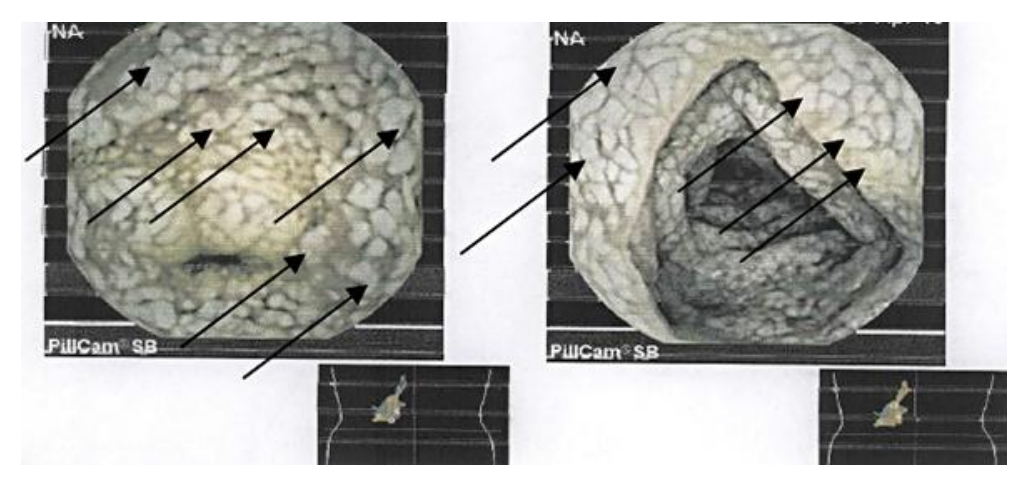

Fig. 3. Case 1. Wireless capsule endoscopy showing white spot lesions in the jejunum (arrows). 


\section{Case Reports in \\ Gastroenterology}

\begin{tabular}{l|l}
\hline \multicolumn{2}{l}{ Case Rep Gastroenterol 2013;7:153-163 } \\
\hline DOI: $\underline{10.1159 / 000348763}$ & $\begin{array}{l}\text { C } 2013 \text { S. Karger AG, Basel } \\
\text { www.karger.com/crg }\end{array}$ \\
\hline
\end{tabular}

Xinias et al.: Primary Intestinal Lymphangiectasia: Is It Always Bad? Two Cases with Different Outcome
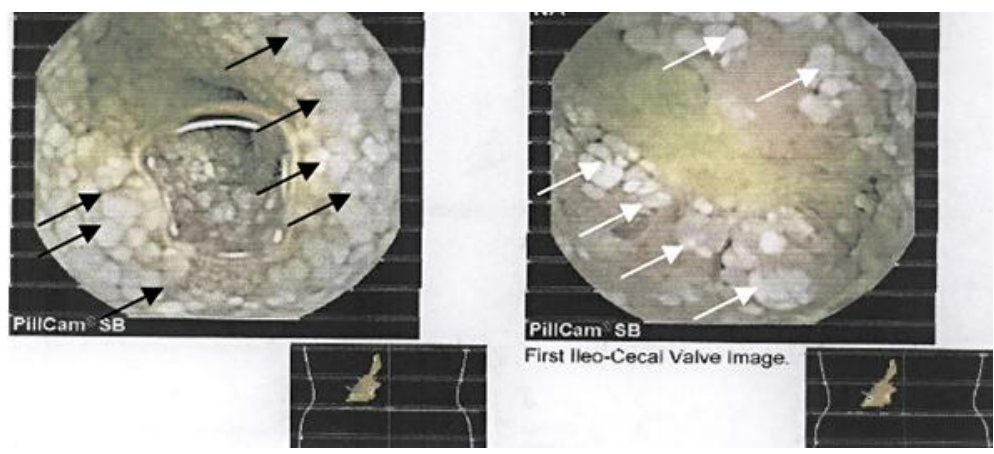

Fig. 4. Case 1. Wireless capsule endoscopy showing very dense white lesions in the ileum (black arrows) to the ileocecal valve area (white arrows).
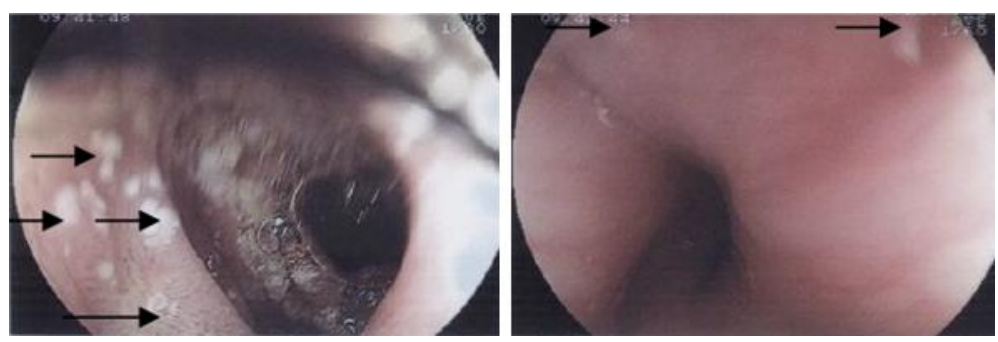

Fig. 5. Case 2. Upper GI endoscopy showing increased lymph diffusion through ruptured lymph vessels appearing as white spots on the duodenal mucosa (arrows).
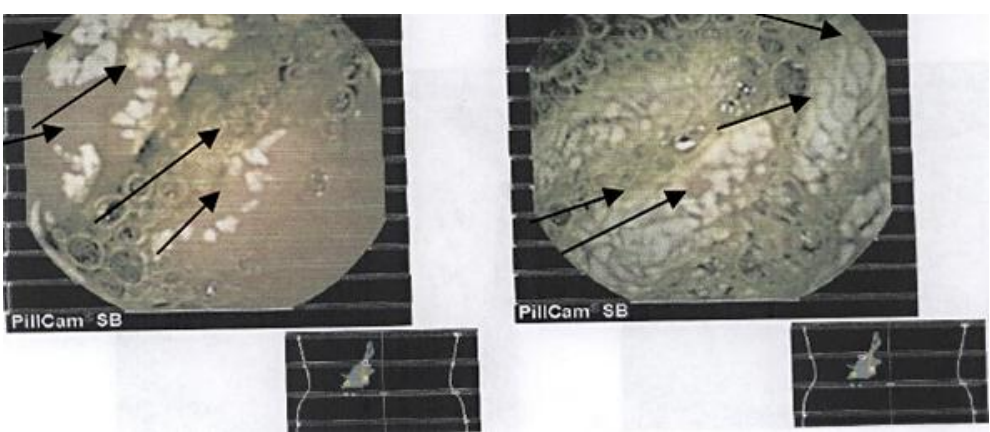

Fig. 6. Case 2. Capsule endoscopy showing white spot lesions in a PIL-affected part of the jejunum. 